\title{
Arkadiusz Januszewski
}

Uniwersytet Technologiczno-Przyrodniczy w Bydgoszczy

e-mail: arkadiusz.januszewski@utp.edu.pl

\section{NARZĘDZIA CONTROLLINGU OPERACYJNEGO W FIRMIE DORADCZO-SZKOLENIOWEJ ${ }^{1}$ OPERATIONAL CONTROLLING TOOLS IN A CONSULTING AND TRAINING SERVICES ENTERPRISE}

DOI: $10.15611 /$ pn.2017.471.16

Streszczenie: W artykule opisano narzędzia controllingu operacyjnego, które wdrożono w firmie doradczo-szkoleniowej GDS FALCO. Stanowią one jeden z efektów prac autora zatrudnionego jako wysoko wykwalifikowany personel w ramach projektu „Region Otwarty na Innowacje", finansowanego z Unii Europejskiej. W projekcie zastosowano następujące metody badawcze: studium przypadku, analizę dokumentacji, wywiad swobodny oraz prototypowanie z wykorzystaniem arkusza Ms Excel. Na opisane w pracy narzędzia controllingu operacyjnego składają się powiązane ze sobą: moduł rejestracji umów z możliwością oceny rentowności projektu na poziomie marży pokrycia uwzględniającej koszty zmienne, moduł planowania i rejestracji wydatków stałych, moduł prognozowania przepływów pieniężnych oraz moduł raportowania służący do wielowymiarowych analiz przychodów i rentowności. Zostały one pozytywnie ocenione przez kierownictwo i są wykorzystywane w procesie zarządzania firmą.

Słowa kluczowe: controlling operacyjny, firma doradczo-szkoleniowa, analizy wielowymiarowe, Ms Excel, controlling projektów.

Summary: The article presents operational controlling tools implemented in the GDS FALCO consulting and training services enterprise. The tools are one of primary effects of the work of the author, acting as Highly Qualified Personnel for the EU-financed "Region Open to Innovations" project. The project involved the application of the following research methods: case study, analysis of documentation, free-form interview and Ms Excel prototyping. The operational controlling tools described in the paper involve four integrated modules: agreement recording module with the project profitability assessment at the level of contribution margin factoring in variable costs, fixed expenditure planning and recording module, cash-flow

${ }^{1}$ Niniejszy artykuł stanowi kontynuację pracy pt. Diagnoza potrzeb informacyjnych $w$ zakresie controllingu operacyjnego $w$ firmie doradczo-szkoleniowej, opublikowanej w Pracach Naukowych Uniwersytetu Ekonomicznego we Wrocławiu nr 440. 
forecasting module and the reporting module for multidimensional revenues and profitability analysis. The tools have received a positive assessment from the management and they are applied in the corporate management process.

Keywords: operational controlling, consulting and training services enterprise, multidimensional analysis, Ms Excel, project controlling.

\section{Wstęp}

Metoda studium przypadku jest często stosowana w badaniach systemów controllingu [Janczyk-Strzała 2014; Major 2007]. Studia przypadków mogą być wykorzystane zarówno do tworzenia teorii [Eisenhardt 2008], jak i do opracowania wzorcowych (referencyjnych) rozwiązań controllingowych, jako optymalnych w danych warunkach funkcjonowania organizacji ze względu na jej charakterystykę [Bieńkowska 2011]. Duże znaczenie samej metody i referencyjnych rozwiązań controllingowych podkreśla wielu autorów [Cooper, Morgan 2008; Knyviene 2014]. Z tego też zapewne powodu $\mathrm{w}$ literaturze przedmiotu $\mathrm{z}$ obszaru controllingu stosunkowo sporo publikacji poświęcono zastosowaniom controllingu w różnych branżach ${ }^{2}$ Trudno jest natomiast znaleźć publikacje dotyczące zastosowań controllingu w firmach doradczo-szkoleniowych [Januszewski 2016].

Niniejszy artykuł stara się wypełnić tę lukę. Jego celem jest przedstawienie narzędzi controllingu operacyjnego opracowanych dla przedsiębiorstwa z sektora MŚP: Grupy Doradczo-Szkoleniowej (GDS FALCO) z Bydgoszczy, która zatrudniła autora artykułu w ramach projektu finansowanego z Europejskiego Funduszu Społecznego na stanowisku konsultanta ds. controllingu ${ }^{3}$. Głównym zadaniem konsultanta było opracowanie metodyki projektowania i wdrażania controllingu operacyjnego przeznaczonej dla małych i średnich przedsiębiorstw z branży usług doradczo-szkoleniowych. Zasadniczy element tej metodyki stanowią opisane w artykule wzorcowe narzędzia controllingu operacyjnego, które zostały z powodzeniem wdrożone w GDS FALCO.

Tworząc opisane w artykule narzędzia controllingu, oprócz studium przypadku, zastosowano następujące metody badawcze: analizę dokumentacji, wywiad swobodny oraz prototypowanie w arkuszu kalkulacyjnym Ms Excel.

2 Przeszukując bibliograficzną bazę publikacji naukowych BAZEKON wg słów kluczowych „studium przypadku” i „controlling”, uzyskuje się 28 wskazań (stan na dzień 4.03.2017 r.). Dużo więcej przykładów można znaleźć w czasopismach branżowych, które specjalizują się w publikowaniu studiów przypadków, takich jak np. „Controlling i Rachunkowość Zarządcza”.

3 „Tymczasowe Zatrudnienie Wysoko Wykwalifikowanego Personelu”, projekt Region Otwarty na Innowacje, Program Operacyjny Kapitał Ludzki. 


\section{Uzasadnienie wyboru arkusza kalkulacyjnego do budowy systemu controllingu operacyjnego dla przedsiębiorstwa z sektora MŚP}

Arkusz kalkulacyjny jest wciąż najczęściej stosowanym przez controllerów narzędziem analitycznym. Z przeprowadzonego przez firmę SunGard badania wynika, że tylko $13 \%$ controllerów wykorzystuje zaawansowane prognostyczne i ostrzegawcze narzędzia Business Intelligence (BI), podczas gdy prawie połowa z nich wciąż analizuje dane, korzystając z arkusza kalkulacyjnego [SunGard 2014; Dyczkowska 2015]. Trzeba jednak zauważyć, że obecnie bardzo dużą rolę w controllingu operacyjnym odgrywają narzędzia do przeprowadzania interaktywnych wielowymiarowych analiz określanych jako OLAP (On-Line Analytical Processing) [Chojnacka-Komorowska 2013, 2016; Chomiak-Orsa 2009; Januszewski 2009, 2010], które stanowią podstawowy element BI. Za ich pomocą analizuje się głównie przychody, koszty i rentowność według różnych przekrojów (wymiarów), rozumianych jako centra odpowiedzialności, takie jak zakłady produkcyjne, klienci, produkty, rynki zbytu, kanały dystrybucji czy sprzedawcy ${ }^{4}$.

Wielowymiarowe analizy można przeprowadzać również w arkuszu kalkulacyjnym Ms Excel, w którym zaimplementowano mechanizm tzw. tabel przestawnych (pivot table). Korzystając z tego mechanizmu, użytkownicy mogą łatwo reorganizować i podsumowywać dane, tworząc, a następnie analizując w sposób interaktywny wielowymiarowe raporty według praktycznie dowolnych wymagan [Peng, Viator, Buchheit 2007]. Przykłady takich możliwości zastosowania tabel przestawnych w literaturze polskiej opisano m.in. w pracach Kesa [2008] oraz Nowosielskiego i Kesa [2010].

Umiejętności korzystania z mechanizmu wielowymiarowej analizy danych za pomocą tabel przestawnych są bardzo przydatne dla menedżerów. Wskazują na to np. Wang, Wang [2015], którzy projektując kurs IT dla kierownictwa MŚP, uwzględnili włączenie do jego programu dostępnych w MS Excel technik OLAP, uznając ich znajomość za niezbędną w zarządzaniu małymi przedsiębiorstwami.

Tym bardziej należy uznać, że narzędzia arkusza Ms Excel są wystarczające dla „,najmniejszych” firm, co potwierdza Dyczkowski, twierdząc, że: ,dla mikrofirm zatrudniających mniej niż 9 pracowników wystarczają na ogół rozwiązania typu Excel BI".

Grupa Doradczo-Szkoleniowa FALCO zatrudnia osiem osób na umowę o pracę oraz, w zależności od potrzeb, kilkunastu trenerów na umowy cywilnoprawne. Zatem wybór arkusza kalkulacyjnego jako narzędzia, w którym zaprojektowano system controllingu operacyjnego, należy uznać za jak najbardziej uzasadniony ${ }^{5}$.

\footnotetext{
${ }^{4}$ Ważną rolę wielowymiarowych i wielosegmentowych analiz w controllingu operacyjnym analiz podkreśla wielu autorów [Nita 2014; Kujawski 2005; Kujawski, Ossowski 2007], o czym wspomniałem w poprzednim artykule.

${ }^{5}$ Dokładniejszą charakterystykę GDS FALCO, realizowanych projektów oraz zdiagnozowanych potrzeb informacyjny przedstawiono w pracy [Januszewski 2016].
} 


\section{Charakterystyka narzędzi controllingu operacyjnego opracowanych dla GDS FALCO}

Rysunek 1 przedstawia ogólną architekturę systemu controllingu operacyjnego dla firmy doradczo-szkoleniowej z sektora MŚP, wykonanego w arkuszu kalkulacyjnym.

Najważniejszym arkuszem, który stanowi podstawę systemu controllingu, jest arkusz Umowy umieszczony w skoroszycie ${ }^{6}$ DANE. Służy on do rejestracji szczegółowych danych o projekcie oraz powiązanej z nim umowie i fakturze. Arkusz Klienci oraz pozostałe arkusze tego skoroszytu zawierają dane typu słownikowego. Arkusz Umowy stanowi źródło danych dla wielowymiarowego (wielosegmentowego) raportowania przychodów i marż pokrycia oraz dla prognozowania przepływów pieniężnych w module CASH-FLOW, do którego są pobierane dane także ze skoroszytu BUDŻET. Moduł BUDŻET służy do planowania i rejestracji wydatków stałych, które nie wykazują bezpośredniego związku z realizowanymi projektami.

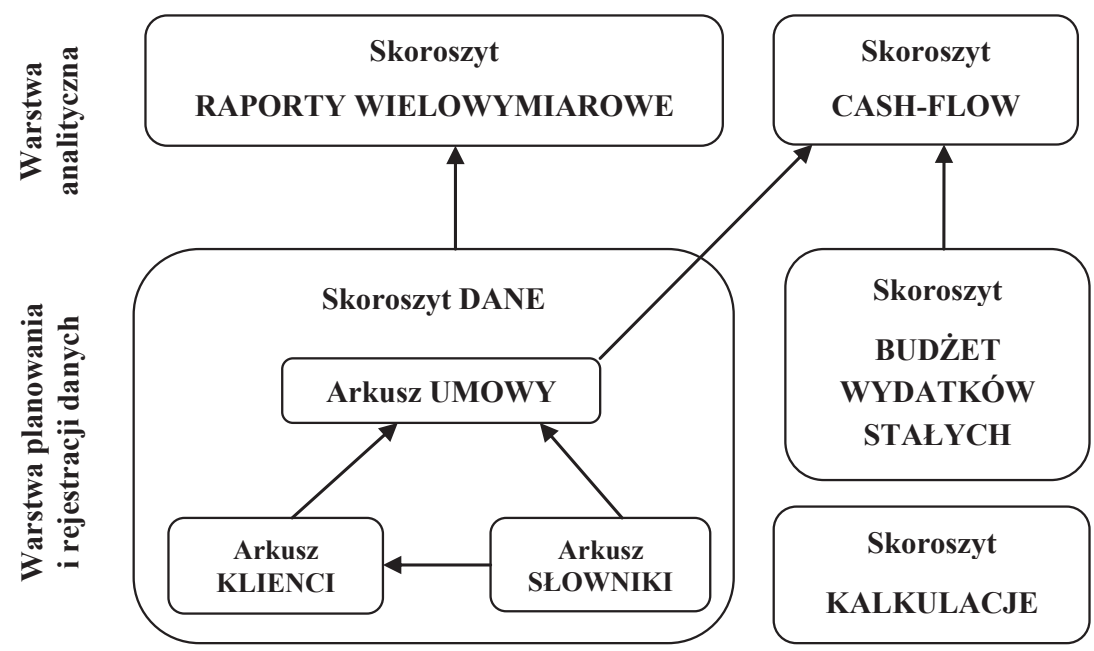

Rys. 1. Ogólna architektura systemu controllingu operacyjnego dla firmy doradczo-szkoleniowej z sektora MŚP

Źródło: opracowanie własne.

Ostatni moduł KALKULACJE zawiera kilka dodatkowych arkuszy, niepowiązanych z żadnym innym skoroszytem. Są to arkusze ułatwiające kalkulację kosztów, takie jak: arkusz kalkulacji oferty szkoleniowej, arkusz kalkulacji kosztów konferencji $\mathrm{z}$ analizą progu rentowności i analizą scenariuszową oraz arkusz kalkulacji oferty projektu wdrożeniowego, które nie będą dalej szczegółowo opisane.

${ }^{6}$ Terminy „skoroszyt” i „moduł” będą stosowane wymiennie. 


\subsection{Charakterystyka modułu DANE}

W arkuszu Umowy zapisywane są informacje o przychodach oraz kosztach bezpośrednio związanych z realizowanymi projektami (umowami). Dla każdego projektu (umowy) określa się m.in.: jedną z czterech dziedzin biznesu, typ, wielkość, tematykę i koordynatora projektu, formę umowy, miejsce i termin realizacji usługi, planowaną i rzeczywistą datę wystawienia faktury oraz terminy płatności. W przypadku projektów szkoleniowych (których w GDS FALCO jest realizowana zdecydowana większość) określa się również liczbę dni szkoleniowych, liczbę grup, liczbę osób oraz nazwiska trenerów, a po wykonaniu usługi także ocenę trenerów przez uczestników szkolenia.

Dla każdego projektu liczone są trzy marże pokrycia w następujący sposób:

Marża pokrycia I = Przychody - Wynagrodzenia trenerów

Marża pokrycia II = Marża pokrycia I - Pozostate koszty bezpośrednie projektu

Marża pokrycia III = Marża pokrycia II - Premia sprzedawcy

Pozostałe koszty bezpośrednie projektu obejmują catering, wynajem sal, koszty materiałów i certyfikatów, koszty noclegów oraz koszty transportu.

Zaproponowana struktura kalkulacji marż pokrycia ma bezpośredni wpływ na raporty analityczne, zaprojektowane w module RAPORTY.

Arkusz Klienci zawiera szczegółowe dane teleadresowe klienta oraz reprezentowaną przez niego branżę i region. Pozostałe arkusze zawierają dane typu słownikowego, takie jak: oddział firmy, branże, regiony, dziedziny biznesu, oferowane usługi, rodzaje, tematyka i wielkość projektów, rodzaje umów, trenerzy i koordynatorzy projektów.

Dane ze słowników pełnią podwójną rolę. Po pierwsze, w momencie wprowadzania danych o nowym projekcie lub kliencie pobiera się z nich automatycznie dane z tzw. list rozwijalnych, co ma zapewnić spójność danych. Po drugie, określają one wymiary analizy przychodów, kosztów i marż pokrycia w module RAPORTY.

\subsection{Charakterystyka modułu BUDŻET}

W module BUDŻET planuje się wydatki, które nie są związane bezpośrednio z realizowanymi projektami, w podziale na lata i miesiące. Struktura budżetu została podzielona na wydatki przewidywalne (planowane) oraz wydatki nieprzewidywalne (nieplanowane).

W wydatkach przewidywalnych ustalono cztery główne grupy nazwane następująco:

1. Pracownicy, w podziale na wydatki związane z wynagrodzeniami, świadczeniami i podróżami służbowymi.

2. Pojazdy, w podziale na wydatki związane $\mathrm{z}$ materiałami, usługami obcymi i ubezpieczeniami.

3. Infrastruktura, w podziale na wydatki związane z pomieszczeniami, wyposażeniem i materiałami biurowymi. 


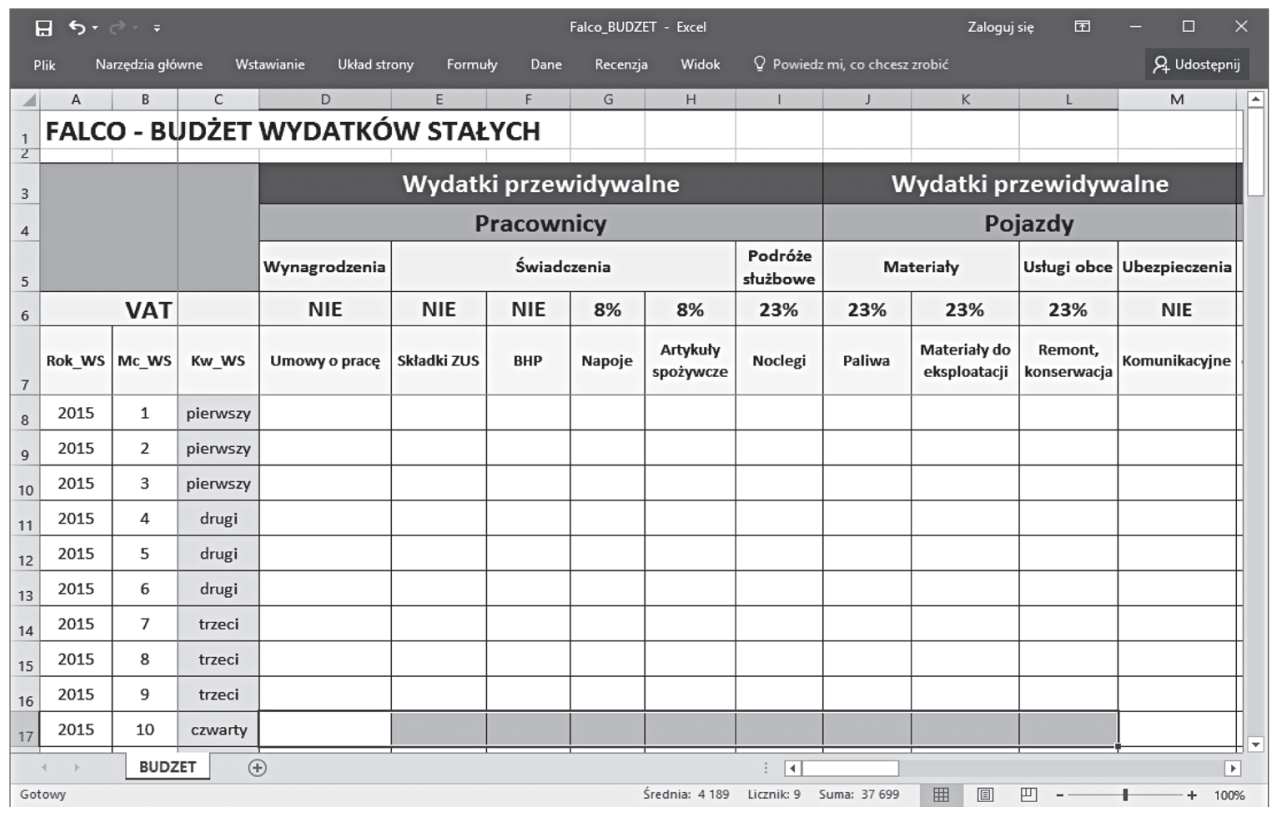

Rys. 2. Fragment struktury „Budżet wydatków stałych”

Źródło: opracowanie własne.

\begin{tabular}{|c|c|c|c|c|c|c|c|c|c|}
\hline & & & \multicolumn{7}{|c|}{ Planowana Suma Wydatków Stałych według stawek VAT } \\
\hline \multicolumn{3}{|c|}{ VAT } & NIE & $8 \%$ & $23 \%$ & Razem Netto & $8 \%$ & $23 \%$ & Razem VAT \\
\hline Rok_WS & S Mc_WS & Kw_WS & \multicolumn{4}{|c|}{ Wartość netto } & \multicolumn{3}{|c|}{ Podatek VAT } \\
\hline 2015 & 1 & pierwszy & 30305 & 197 & 21818 & 52320 & 16 & 5018 & 5034 \\
\hline 2015 & 2 & pierwszy & 34661 & 236 & 22051 & 56949 & 19 & 5072 & 5091 \\
\hline 2015 & 3 & pierwszy & 31121 & 169 & 24596 & 55886 & 13 & 5657 & 5671 \\
\hline 2015 & 4 & drugi & 24248 & 232 & 21010 & 45490 & 19 & 4832 & 4851 \\
\hline 2015 & 5 & drugi & 30839 & 440 & 22780 & 54059 & 35 & 5239 & 5275 \\
\hline 2015 & 6 & drugi & 30822 & 396 & 40916 & 72134 & 32 & 9411 & 9442 \\
\hline 2015 & 7 & trzeci & 35348 & 217 & 14979 & 50545 & 17 & 3445 & 3463 \\
\hline 2015 & 8 & trzeci & 30542 & 23 & 19128 & 49692 & 2 & 4399 & 4401 \\
\hline 2015 & 9 & trzeci & 25675 & 316 & 20218 & 46209 & 25 & 4650 & 4675 \\
\hline 2015 & 10 & czwarty & 27591 & 519 & 23106 & 51217 & 42 & 5314 & 5356 \\
\hline 2015 & 11 & czwarty & 27358 & 519 & 22498 & 50375 & 42 & 5175 & 5216 \\
\hline 2015 & 12 & czwarty & 27358 & 519 & 20953 & 48830 & 42 & 4819 & 4861 \\
\hline
\end{tabular}

Rys. 3. Tabela planowanych wydatków stałych wg stawek VAT

Źródło: opracowanie własne. 
4. Administracja, zarządzanie i marketing, w podziale na wydatki związane $\mathrm{z}$ reprezentacją, usługami obcymi.

W przypadku większości wydatków zastosowano jeszcze dodatkowy podział (np. wydatki związane z pomieszczeniami podzielono na: „,najem, dzierżawę, opłaty czynszowe”, ,ubezpieczenia majątkowe” oraz „energię i media komunalne”).

Wśród wydatków nieprzewidywalnych również wyróżniono cztery grupy:

1. Pracownicy, w podziale na wydatki związane z umowami cywilno-prawnymi (które nie są przewidziane jako koszty bezpośrednie projektu), pozostałymi wynagrodzeniami oraz szkoleniami pracowników.

2. Wyposażenie (bez dalszego podziału).

3. Usługi obce, w podziale na usługi doradcze, usługi szkoleniowe, usługi gastronomiczne oraz remonty i konserwacje budynków.

4. Inne wydatki (bez dalszego podziału).

Dla każdego wydatku, zarówno przewidywalnego, jak i nieprzewidywalnego, na najniższym poziomie szczegółowości wprowadzono parametr informujący o stawce podatku VAT lub zwolnieniu z tytułu tego podatku. Arkusz BUDŻET zawiera też tabelę, która przedstawia sumy planowanych wydatków stałych wg różnych stawek VAT. Dzięki temu w module CASH-FLOW jest możliwe prognozowanie rozliczenia podatku VAT. Fragment struktury budżetu wydatków stałych przedstawiono na rys. 2, a tabelę z planowanymi sumami podatku VAT na rys. 3 .

\subsection{Charakterystyka modułu CASH-FLOW}

Moduł CASH-FLOW został utworzony w celu wspomagania zarządzania przepływami gotówki wynikającymi z rozliczenia VAT w ujęciu kwartalnym oraz pozo-

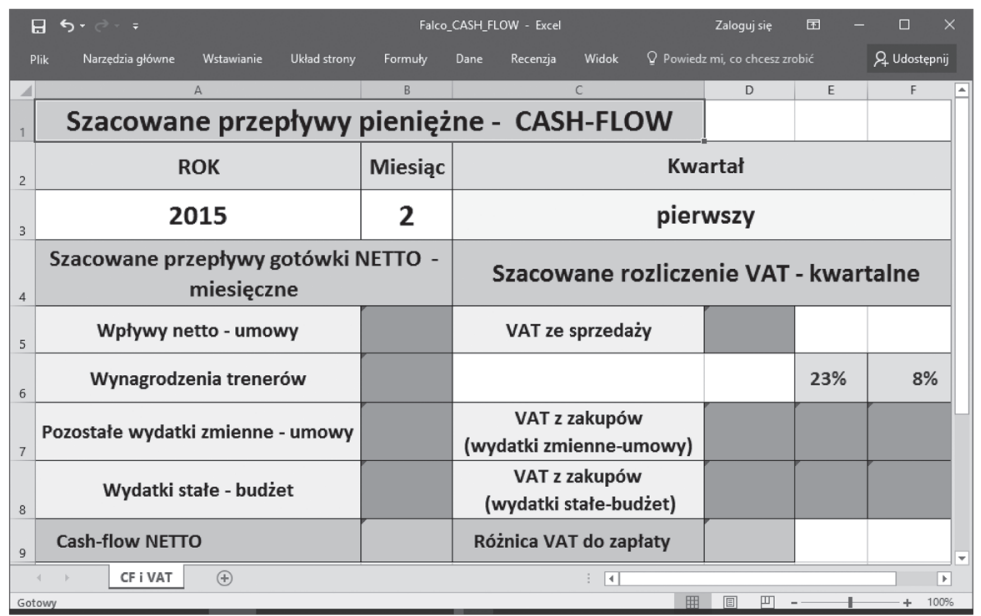

Rys. 4. Raport z prognozowanych przepływów pieniężnych

Źródło: opracowanie własne. 
stałymi przepływami gotówki w ujęciu miesięcznym. Po wprowadzeniu interesującego nas roku i miesiąca wyliczane są planowane wpływy netto z realizacji projektu, planowane wynagrodzenia trenerów oraz pozostałe planowane wydatki zmienne $\mathrm{z}$ arkusza Umowy. Wykorzystuje się przy tym funkcję „SUMA.WARUNKÓW”, umożliwiającą zsumowanie tylko tych wartości, które dotyczą konkretnego roku i miesiąca. Jednocześnie pobiera się dane o podatku VAT (dla którego w arkuszu Umowy na podstawie planowanej daty wystawienia faktury i terminu płatności ustalono rok i miesiąc pojawienia się zobowiązania z tytułu podatku VAT). Dane o wydatkach stałych i podatku VAT są pobierane z arkusza BUDŻET. Raport o planowanych przepływach pieniężnych przedstawiano na rys. 4 .

\subsection{Charakterystyka modułu RAPORTY}

Moduł RAPORTY zawiera kilkadziesiąt wielowymiarowych raportów analitycznych wykonanych za pomocą mechanizmu tabel przestawnych. Służą one do analizy przychodów, kosztów i marż pokrycia. Każdy z raportów przygotowano tak, aby dane można było filtrować według roku i miesiąca. Raporty można podzielić na następujące grupy:

1. Jednowymiarowe raporty służące do: analizy wartości przychodów i 3 stopni marż pokrycia, analizy struktury przychodów i 3 marż pokrycia oraz analizy 3 wskaźników marż pokrycia, które informują o rentowności. Łącznie przygotowano 7 raportów dla następujących kategorii (wymiarów): obszar (dziedzina biznesu), typ projektu, tematyka projektu, klient, branża, trener, koordynator projektu.

2. Dwuwymiarowe raporty służące do: analizy wartości przychodów oraz struktury przychodów w 3 różnych układach. Łącznie przygotowano 11 raportów dla następujących par kategorii (wymiarów): obszar (dziedzina biznesu) <-> typ projektu, obszar (dziedzina biznesu) <-> rozmiar projektu, obszar (dziedzina biznesu) $<->$ klient, obszar (dziedzina biznesu) <-> branża, obszar (dziedzina biznesu) <-> koordynator projektu, typ projektu $<->$ klient, typ projektu $<->$ branża, typ projektu $<->$ koordynator projektu, rozmiar projektu $<->$ klient; rozmiar projektu <-> branża; rozmiar projektu $<->$ koordynator.

3. Dwuwymiarowe raporty służące do: analizy wartości marży 3 stopnia oraz struktury marży 3 stopnia w 3 różnych układach. Łącznie przygotowano 11 raportów dla następujących par kategorii (wymiarów): obszar (dziedzina biznesu) <-> typ projektu, obszar (dziedzina biznesu) <-> rozmiar projektu, obszar (dziedzina biznesu) <-> klient, obszar (dziedzina biznesu) <-> branża, obszar (dziedzina bizne$\mathrm{su})<->$ koordynator projektu, typ projektu $<->$ klient, typ projektu <-> branża, typ projektu <-> koordynator projektu, rozmiar projektu <-> klient; rozmiar projektu $<->$ branża; rozmiar projektu $<->$ koordynator.

Przykładowy raport dwuwymiarowy, który służy do analizy przychodów struktury przychodów dziedziny biznesu według wielkości projektu, przedstawiono na rys. 5 . Ukazuje on, że zdecydowana większość przychodów jest generowana przez projekty 


\begin{tabular}{|c|c|c|c|c|c|}
\hline Przychód netto & Obszar & & & & \\
\hline Wielkość projektu & BP & LT & MS & HR & Suma \\
\hline Duży & $23.3 \%$ & & $4.2 \%$ & $72.5 \%$ & $100.0 \%$ \\
\hline Średni & $22.4 \%$ & $7.6 \%$ & $26.0 \%$ & $44.0 \%$ & $100.0 \%$ \\
\hline Mały & $35.0 \%$ & $3.2 \%$ & $34.9 \%$ & $26.8 \%$ & $100.0 \%$ \\
\hline Suma & $25.8 \%$ & $3.5 \%$ & $19.4 \%$ & $51.3 \%$ & $100.0 \%$ \\
\hline
\end{tabular}

Rys. 5. Przykładowy dwuwymiarowy raport struktury przychodów dziedzin biznesu według wielkości projektu

Źródło: opracowanie własne.

z obszaru HR (Human Resource Management) - ponad 51\%, przy czym w grupie projektów dużych jest to nawet ponad $72 \%$.

\section{Podsumowanie}

W przedsiębiorstwach z sektora MŚP, a tym bardziej w mikrofirmach, wystarczającym środowiskiem dla zbudowania systemu controllingu operacyjnego jest arkusz kalkulacyjny. Zaprojektowany dla GDS FALCO zestaw narzędzi umożliwia realizację dwóch najważniejszych zadań, które określiło kierownictwo firmy. Po pierwsze, oczekiwano stworzenia możliwości przeprowadzania wielowymiarowych analiz przychodów i marż pokrycia według różnych przekrojów, co miało pomóc w ustaleniu niewykorzystanych obszarów działania firmy oraz obszarów o najwyższej i najniższej rentowności (dziedzin biznesu, tematyki, rodzaju i wielkości projektu, branży, regionu itd.). Po drugie, narzędzia miały zapewnić możliwość prognozowania przepływów pieniężnych, zarówno z tytułu rozliczenia podatku VAT, jak i wszystkich pozostałych.

Opracowane narzędzia spełniają sformułowane przez kierownictwo firmy oczekiwania. Podstawowy arkusz Umowy zapewnia planowanie i rozliczanie przychodów i kosztów bezpośrednich na poziomie pojedynczych projektów. Dzięki szczegółowej charakterystyce każdego projektu i zastosowaniu mechanizmu tabel przestawnych możliwe jest przeprowadzenie wielowymiarowej analizy przychodów i marż pokrycia. Wyniki działalności firmy można analizować za pomocą kilkudziesięciu raportów według m.in. takich wymiarów, jak: branża, klient, dziedzina biznesu, oddział firmy oraz wielkość, typ, tematyka, koordynator i projektu. Zaprojektowany moduł CASH-FLOW, który czerpie dane o wydatkach zmiennych związanych z projektami $\mathrm{z}$ arkusza Umowy, a dane o wydatkach stałych, z nimi bezpośrednio niezwiązanych, ze skoroszytu BUDŻET, zapewnia natomiast prognozowanie przepływów pieniężnych dla wskazanego miesiąca i kwartału.

Na zakończenie warto dodać, że opisane w artykule narzędzia controllingu operacyjnego zostały wdrożone w firmie GDS FALCO i pozytywnie ocenione przez jej kierownictwo. 


\section{Literatura}

Bieńkowska A., 2011, O potrzebie badań modelowych i opracowania wzorcowych rozwiązań controllingu, Zeszyty Naukowe Uniwersytetu Ekonomicznego w Poznaniu, nr 187, s. 17-27.

Chojnacka-Komorowska A., 2013, Wykorzystanie systemów Business Intelligence $w$ controllingu finansowym, Prace Naukowe Uniwersytetu Ekonomicznego we Wrocławiu, nr 289, s. 130-139.

Chojnacka-Komorowska A., 2016, Interaktywne przetwarzanie analityczne (OLAP) w controllingu finansowym, Prace Naukowe Uniwersytetu Ekonomicznego we Wrocławiu, nr 440, s. 119127.

Chomiak-Orsa I., 2009, Zastosowanie Business Intelligence w controllingu, Prace Naukowe Uniwersytetu Ekonomicznego we Wrocławiu, nr 56, s. 58-66.

Cooper D., Morgan W., 2008, Case study Research in Accounting, Accounting Horizons, no. 22(2), s. $159-178$.

Dyczkowska J., 2015, Nowoczesne narzędzia raportowania menedżerskiego w kontekście roli wspótczesnych controllerów, Prace Naukowe Uniwersytetu Ekonomicznego we Wrocławiu, nr 398, s. $121-133$.

Dyczkowski M., 2016, Analiza efektywności ekonomicznej zastosowania systemów klasy Business Intelligence w sektorze MŚP: podstawy metodyczne, Studies \& Proceedings of Polish Association for Knowledge Management, no. 78, s. 22-33.

Eisenhardt K.M., 1989, Building theories from case study research, Academy of Management Review, vol. 14 , no. 4, s. 532-550.

Janczyk-Strzała E., 2014, Zastosowanie metod badania controllingu w Polsce - próba analizy na wybranych przykładach, Acta Universitatis Lodziensis, Folia Oeconomica, vol. 4(304), s. 69-80.

Januszewski A., 2009, Cechy systemów klasy Business Intelligence stosowanych w controllingu, Studia i Materiały Polskiego Stowarzyszenia Zarządzania Wiedzą, vol. 18, s. 78-87.

Januszewski A., 2010, Systemy rachunkowości i controllingu, [w:] Informatyka gospodarcza, C.H. Beck, Warszawa, s. 561-613.

Januszewski A., 2016, Diagnoza potrzeb informacyjnych $w$ zakresie controllingu operacyjnego $w$ firmie doradczo-szkoleniowej, Prace Naukowe Uniwersytetu Ekonomicznego we Wrocławiu, nr 440, s. $215-224$.

Kes Z., 2008, Wyznaczenie mierników perspektywy klienta z wykorzystaniem arkusza kalkulacyjnego Excel, Prace Naukowe Akademii Ekonomicznej we Wrocławiu, nr 1196, s. 48-66.

Knyviene I., 2014, A new approach: the case study method in accounting, Economics \& Management, vol. 6 , iss. 4, s. $158-168$.

Kujawski J., 2005, Model oceny rentowności centrów zysku z wykorzystaniem standardowej marży pokrycia, Prace i Materiały Wydziału Zarządzania Uniwersytetu Gdańskiego, s. 107-118.

Kujawski J., 2010, Koncepcja rachunku marż pokrycia projektu, Prace Naukowe Uniwersytetu Ekonomicznego we Wrocławiu, nr 123, s. 267-276.

Kujawski J., Ossowski M., 2007, Wykorzystanie wieloblokowego i wielostopniowego rachunku wyników w działalności ustugowo-handlowej, Prace i Materiały Wydziału Zarządzania Uniwersytetu Gdańskiego, nr 4, s. 49-58.

Major A., 2007, System controllingu w przedsiębiorstwie. Studia przypadków zastosowań w warunkach polskich, Wydawnictwo Naukowe Semper, Warszawa.

Nita B., 2014, Zakres wewnętrznych analiz dotyczacych rentowności w controllingu operacyjnym, Zeszyty Naukowe Uniwersytetu Szczecińskiego, Finanse, Rynki Finansowe, Ubezpieczenia, nr 66, s. $75-86$.

Nowosielski K., Kes Z., 2010, MS Excel we wspomaganiu controllingu sprzedaży: studium przypadku, Zeszyty Naukowe Wyższej Szkoły Bankowej w Poznaniu, nr 28, s. 293-305. 
Peng J., Viator R., Buchheit S., 2007, An experimental study of multidimensional hierarchical Accounting data: Drill-down paths can influence economic decisions, Journal of Information Systems, vol. 21 , no. 2, s. 69-86.

SunGard, 2014, Assessing Your Firm's Business Intelligence Maturity.

Wang S., Wang H., 2015, Design and delivery of a new course of information technology for small business, Journal of Information Systems Education, vol. 26(1), s. 37-44. 